\title{
Searching for the Origin of Agriculture in East Asia
}

\author{
Yuriii E. Vostretsov* \\ Institute of History, Archaeology and Ethnology \\ of the Peoples of the Far-East \\ Far-Eastern Branch of the RAS \\ Vladivostok, Russian Federation
}

Received 09.10.2019, received in revised form 04.03.2020, accepted 24.04.2020

\begin{abstract}
Neolithization of East Asia took place against the background of catastrophic landscape and environmental changes. The "sudden" appearance of early farmers in already developed type of cultures such as Peiligang and Cishan has not been studied enough. It is necessary to clarify the origins and reasons for the wide distribution of both early farmers and the "wide range of hunter-gatherers." The article considers the territory where the transition to agriculture could take place, as well as a set of environmental influence factors in the late Pleistocene and early Holocene, which influenced the choice of behavioural survival strategies.

The paleogeographic model of transition to agriculture in East Asia proposed in the article, considers the paleoplain that existed in the territory of the modern shelf of the Yellow Sea as the most likely area where plant domestication could originate. The tendencies of changes in the landscape structure of the paleoplain territory during the cooling and warming periods, associated with sea level fluctuations, have been reconstructed. The boundaries of maximum marine transgression, as well as the zone of flooding and destruction of the early farmers' settlements have been determined. It has been found out that all the preserved sites of early cultivators and farmers are on the border of the marine transgression peak, creating the effect of their "sudden" appearance.

In the context of paleogeographic reconstructions, it has been suggested that transition to the cultivation and domestication of millet and rice started simultaneously on the paleoplain during the cooling of the Older and Younger Dryas, and was additionally "motivated" by two subsequent coolings at the early Holocene.

As a result of the marine transgression, the mouths of the Huang He and the Yangtze rivers diverged to the south and north, as well as the territorial specialisation of early farmers in cultivating rice and millet. The similarity of some features of the material culture of the Early Neolithic of North and South China is determined by the fact that they originated from a common centre.
\end{abstract}

Keywords: origins of agriculture, archaeology, paleogeography, East Asia.

Research area: archeology.

\footnotetext{
(C) Siberian Federal University. All rights reserved

* Corresponding author E-mail address: vost54@mail.ru ORCID: 0000-0002-3717-4528
} 
Citation: Vostretsov, Yu.E. (2020). Searching for the origin of agriculture in East Asia. J. Sib. Fed. Univ. Humanit. Soc. Sci., 14(1), 98-110. DOI: 10.17516/1997-1370-0573.

\section{Introduction}

The most significant turning point in the behavioural evolution of mankind is food production development. The emergence of cereal farming was its most striking manifestation. This topic has long been of researchers interest in various parts of the world. Most authors agree that transition to agriculture in Eurasia took place in two centres of domestication in Western and East Asia, and it was associated with climate warming at the late Pleistocene early Holocene. Over the past two decades, there has been a sharp increase in the interest to various aspects of this process, associated with an increase in the quantity and quality of data, ranging from "building a niche", domestication of plants and associated weeds, and finishing with the development and dissemination of cultures, languages and ethnic groups (Stevens, Fuller, 2017: 175). It has turned out that the transition to the actual cultivation of domesticated plants was preceded by a long period of cultivation of their wild forms, which were gradually domesticated. It required a lot of time, from 1,000 to 4,000 years (Fuller et al., 2009; Cohen, 2011: 273; Stevens, Fuller, 2017: 156, 167), a lot of different plant species were involved in the process, but not all of them were fully domesticated. Useless attempts to domesticate plants are, probably, visible along this path (Stevens, Fuller, 2017: 159). It has also turned out that transition to sedentary lifestyle associated with agriculture took place gradually and in accordance with an increase in the nutritional value of cultivated plants.

At the same time, according to Bar-Yosef, there is a clear avoidance of in-depth consideration of the paleogeographic conditions in which domestication processes took place (Bar-Yosef, 2011: 177). The influence of climate cooling, in particular, of the Younger Dryas, was mainly evaluated as a stimulatory factor for the selection of behavioural decisions in the area of plant cultivation (Cohen, 2011: 274; Bar-Yosef, 2011: 178). The fact, that the reconstructions of the landscape structures of the territories where plants cultivation and trends in their changes due to climate warming took place, were left without due attention, is surprising. This is exactly what is observed in East Asian studies. The author of the present paper believes that environmental changes that formed the resource potential of communities stimulated people to search for certain behavioural strategies in the formation of optimal life support systems for survival (Vostretsov, 2016). This situation is especially relevant for East Asia, where the landscape structure of the territory was significantly different from that in Western Asia, and landscape and climate changes were more noticeable and catastrophic. Consideration of these aspects can help to come closer to understanding the place and conditions of the population's transition from gathering to agricultural practice.

East Asia remains an understudied region on many issues. The issue of transition to productive economy and sedentary lifestyle has been studied relatively recently. Archaeological data are scarce, and they are accumulated slowly. In this situation, the construction of models of the processes under study, which would allow integrating the available paleogeographic and archaeological data and optimise the direction of the search for missing information, is relevant.

It is known that the earliest agricultural communities of Peiligang and Cishan cultures appeared in the middle reaches of the Huang He about 10,000-9,000 cal. years ago. Settlements with an area of 1-2 hectares, fortified with ditches and moats, were found there. Semisubterranean houses were of a round shape, garbage pits and numerous barns were found next to them, with a significant amount of millet remains in some of them. The material culture of the sites' population is represented by fragments of pottery vessels, stone adzes, axes and hand plows, as well as grinding stone on legs. Excavated special burial sites, earthen platforms and buried treasures are believed to be signs of the ritual activities of the settle- 
ments' dwellers (Cohen, 2011: 279-283). Communities of the Peiligang and Cishan cultures appear "suddenly", in an already developed form, and do not make an impression of "early Neolithic farmers" (Vostretsov, 2012). Moreover, the roots of these cultures are traced nowhere in East Asia.

The "sudden appearance" of farmers cannot be considered without taking into account the paleogeographic situation. If paleogeographic data are integrated with archaeological and archaeobotanical ones, as well as observations from the field of human behavioural ecology, it is possible to try to determine where and how the changing environmental conditions of East Asia contributed to the appearance of early farmers among hunter-gatherers.

\section{Trends in Environmental Changes and Archaeological Data}

Most researchers agree that the process of transition from gathering to farming had a common incentive in the form of environ- mental changes in the late Pleistocene - early Holocene (Liu, 2008; Cohen, 2011; Bar-Yosef, 2011; Shevkomud, Ianshina, 2012; Liu, Chen, 2012). In the continental zone of East Asia, it was mainly connected with the development of processing and storage technologies for starchy foods (Liu, 2008), and on the coast it was also connected with the exploitation of estuarine and marine resources.

Schematically, the transition to agriculture in East Asia is as follows. In the vast territory from northern China to the Middle Amur as a result of a gradual climate warming after the turn of 20,000-16,000 cal BP, a plant resource base (in the form of nuts and millet), which was supplemented by lake and estuarine resources, was gradually formed. In total, they created conditions for the emergence of sedentary lifestyle skills based on the exploitation of food resources suitable for long-term storage.

In the middle course of the Huang He river, in the valleys with favourable microclimate, four groups of sites (Fig. 1), such as in Xiach-
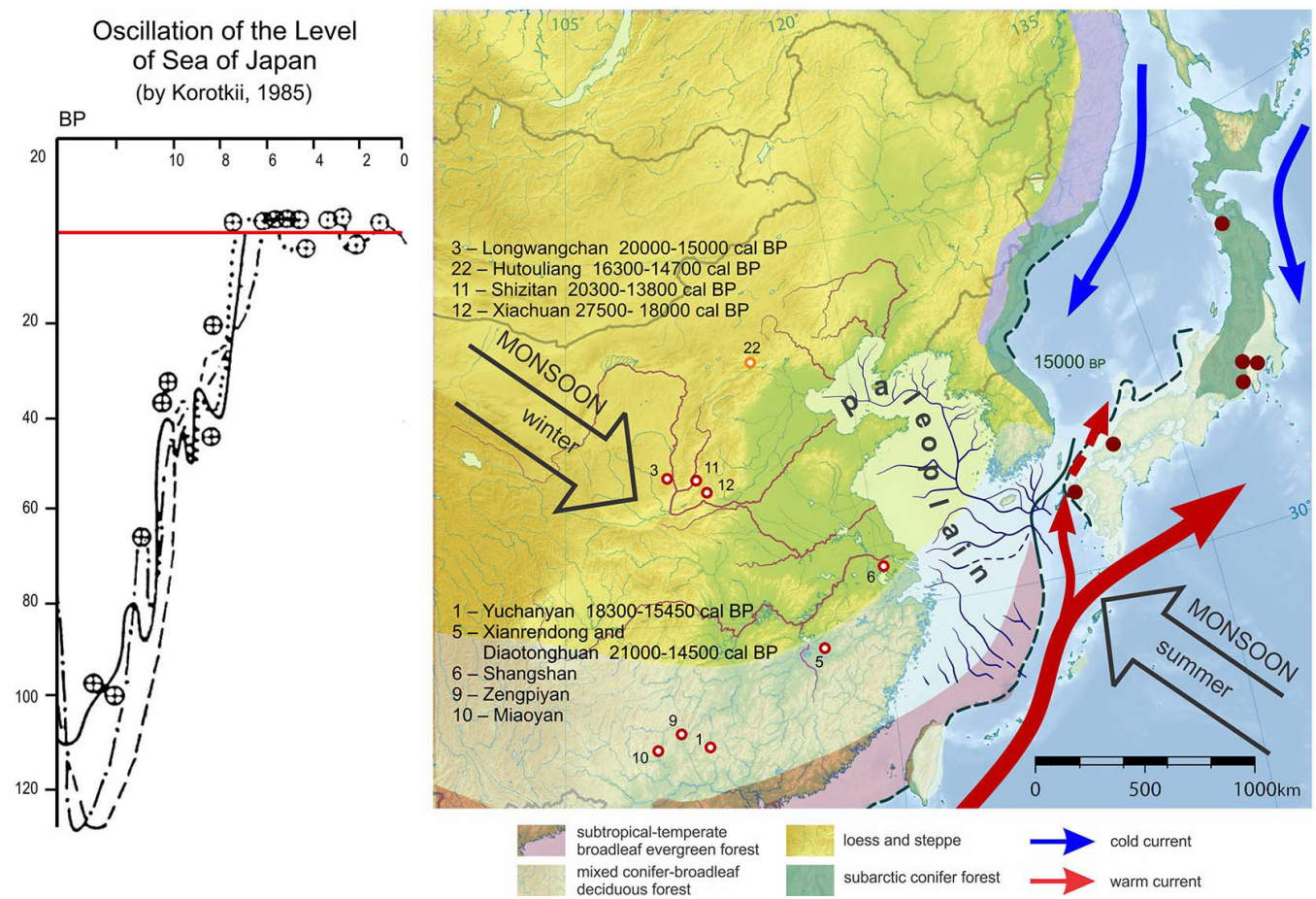

Fig. 1. Sea level change curve in the late Pleistocene-Holocene (on the left). Reconstruction of the coast of East Asia about 15,000 years ago, and archaeological sites of that period (Based on: Liu, Chen, 2012: Fig. 3.8) (on the right) 
uan (approx. 25,000 cal BP and approx. 15,000 cal BP), Shizitan (approx. 20,000-9,000 cal BP), Hutouliang (approx. 16,300-14,700 cal BP) and Longwangchan (20,000-15,000 cal BP) (Liu, 2008; Liu, Chen, 2012) appeared, where numerous microplates and grinding stones were found (Liu, Chen, 2012: 46-51). Some of the flakes found in the settlement at the Xiachuan site, have traces similar to those obtained on experimental samples when cutting off panicles (Liu and Chen, 2012: 47). In addition to that, it was found that some pestles were used to treat seeds with husks, presumably wild millet. Residential horizons of the population dwelling on the multilayer sites in Shizitan, alternate with several meters thick loess clusters. Microplates, grinding plates and grinding stones from these settlements indicate the treatment of small seeds of herbaceous plants. On the grinding stones from layer 9, formed approximately 12,700-11,600 cal BP, starch residues of numerous plants, including acorns (Quercus sp.) and herbs (Panicoideae and Pooideae) were found, and these two taxa account for $73 \%$ of the total number of starch granules, or $95 \%$ of the identified ones. A small part is represented by beans (family Fabaceae, tribe Phaseoleae) and tuberous (Dioscorea sp.). The number of sites with grinding stones in the interval from 25,000 to 12,000 cal BP had increased, and they disappeared by the early Holocene. Thus, in the late Pleistocene in the middle reaches of the Huang He river the use of herbaceous plants increased, and microplates, grinding plates and stones became ubiquitous components of the material culture of these groups of monuments (Liu, Chen, 2012: 50).

Approximately 16,000 cal BP climate conditions improved, and forest landscapes returned to loess areas. The late Pleistocene sharp climate warming at the boundary of the Bølling-Allerød period (approximately 14,60012,800 cal BP) also contributed to the transition of hunter-gatherers to a partial and complete settlement, population growth and resettlement to acceptable for habitat territories of East Asia up to the Middle Amur (Liu, 2008). Similar events can be traced on the Japanese archipelago in the Incipient Jomon (Immamura, 1996).
At the same time, the pre-farming Natufian culture flourished in Western Asia.

The early Neolithic cultures of the Middle Amur, that one way or another switched to sedentary lifestyle (Osipovska, Gromatukha) existed approximately between 16,000-11,500 cal BP and disappeared in the early Holocene without leaving successors (Shevkomud, Ianshina, 2012: 231). They appeared suddenly, and there are no sites with Upper Paleolithic industries in their territories (Ianshina, 2008: 144). All of them had been developing, although in contact with each other, but each had its own independent way (Shevkomud, Ianshina, 2010: 67-70; Shevkomud, Ianshina, 2012: 231). At the same time, if the Gromatukha culture population has some succession in the stone industry with the Upper-Paleolithic traditions, Osipovska culture appeared suddenly and in a "finished" form (Shevkomud, Ianshina, 2012: 229). All the main Neolithic features: pottery, arrowheads, fishing sinkers, dwellings and stone sculpture are typical for these cultures (Ianshina, 2008). Moreover, the Gromatukha culture pottery is more developed and differs in stereotypes of decorative design from Osipovska culture (Shevkomud, Ianshina, 2012: 229). The pottery of the Early Neolithic cultures of the Middle Amur is characterised by the developed form of a cord-marked ornament, a vertical and horizontal zigzag, a comb ornament and a net, there are types of ornament that later dominated in the agricultural sites' materials. At the same time, the agricultural settlements of this period in East Asia are still unknown. In this connection, the question where and in which population did these types of ornaments appear initially, arises. Currently, there are also no known sites that in lifestyle and social structure of their population could be considered as transitional ones from the advanced hunter-gatherers to the "low-level" cultivators of wild plants, and from them to the early farmers of the Peiligang-Cishan type. It is obvious that farmers were not formed in the middle reaches of the modern Huang He river, but somewhere else. Where was that most suitable place for the transition to agriculture in terms of the set of landscape and environmental conditions? It is assumed that the most likely, if not the only 
place was the paleoplain on the modern shelf of the Yellow Sea (Fig. 1). It should be noted that references to paleogeographic reconstructions, suggesting the existence of this territory, were made by individual authors (Liu, Chen, 2012: Fig. 2.7, 39, Fig. 3.8). But the fact that the researchers involved in studying the origin of agriculture limited themselves to this, neglecting the analysis of the landscape and climate conditions, as well as reconstruction of adaptive processes on the paleoplain, is surprising.

Cohen rightly asserts that early Neolithic cultures arose and developed accompanied by the invention and spread of millet and rice cultivation practices within a wide social network and information exchange that arose in the relationships of the Upper Palaeolithic hunter-gatherer societies (Cohen, 2011). Consider the variant of where these relationships took place. To what extent the territory of the Yellow Sea paleoplain corresponds to these char- acteristics compared with the lower and middle reaches of the Huang He river. In this regard, it is necessary to consider the reconstruction of the landscape and climate conditions of the paleoplain and the dynamics of their changes.

\section{Reconstruction of landscape and climate conditions \\ of the Yellow Sea paleoplain}

About 16,000 years ago the territory of East Asia was different from the modern one not only in climate conditions, but in landscape characteristics as well (Fig. 1) (Liu, Chen, 2012: Fig. 3.8). Sea level was lower than the present one by more than $100-120 \mathrm{~m}$. There was a rather flat, well-drained paleoplain on the shelf of the Yellow and East China Seas, and the coast was replete with small and large estuaries. The paleoplain area was more than 416 thousand $\mathrm{km}^{2}$, which is much bigger than the area of the Great Chinese Plain (about 325 thousand $\mathrm{km}^{2}$ ),

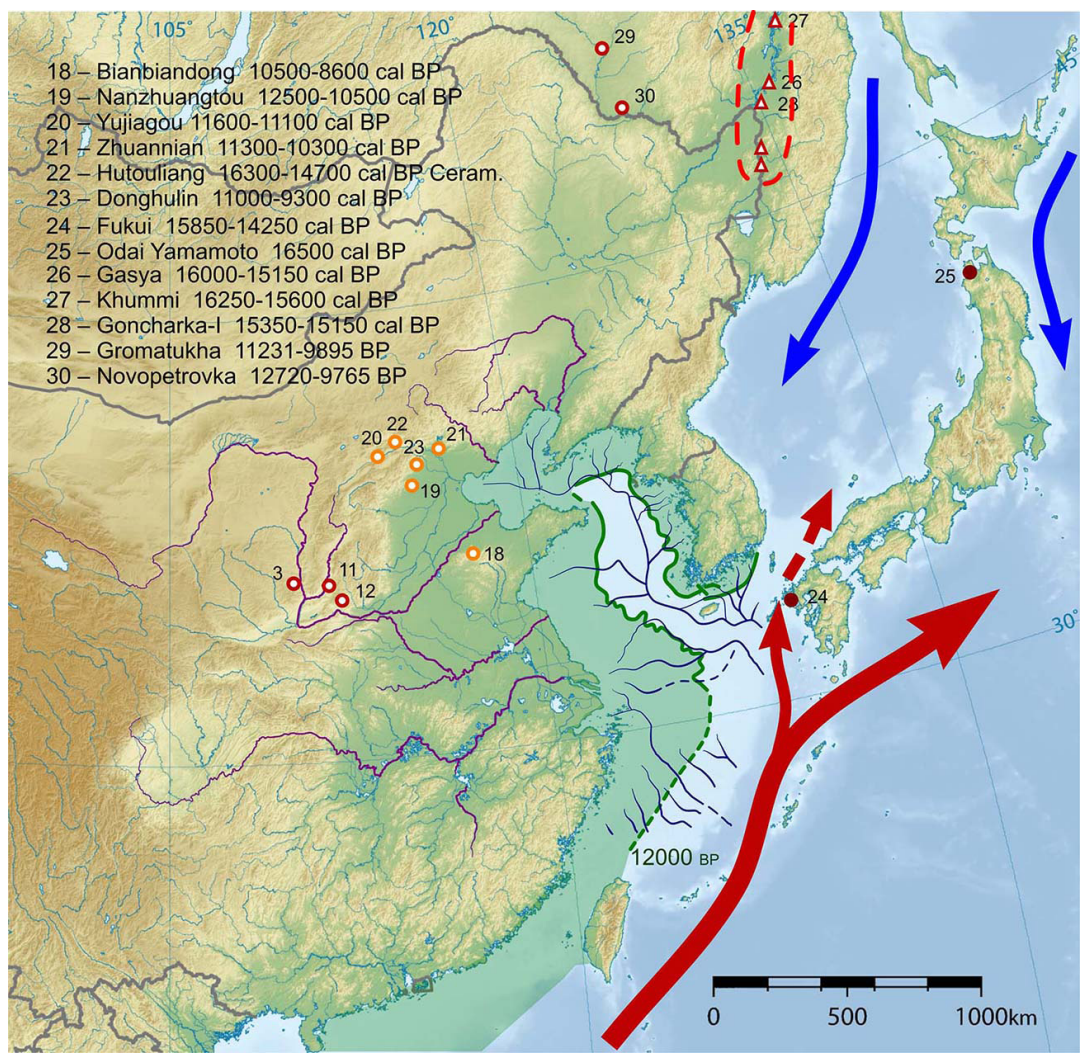

Fig. 2. Reconstruction of the coast of East Asia about 12,000 BP, and archaeological sites of that period 


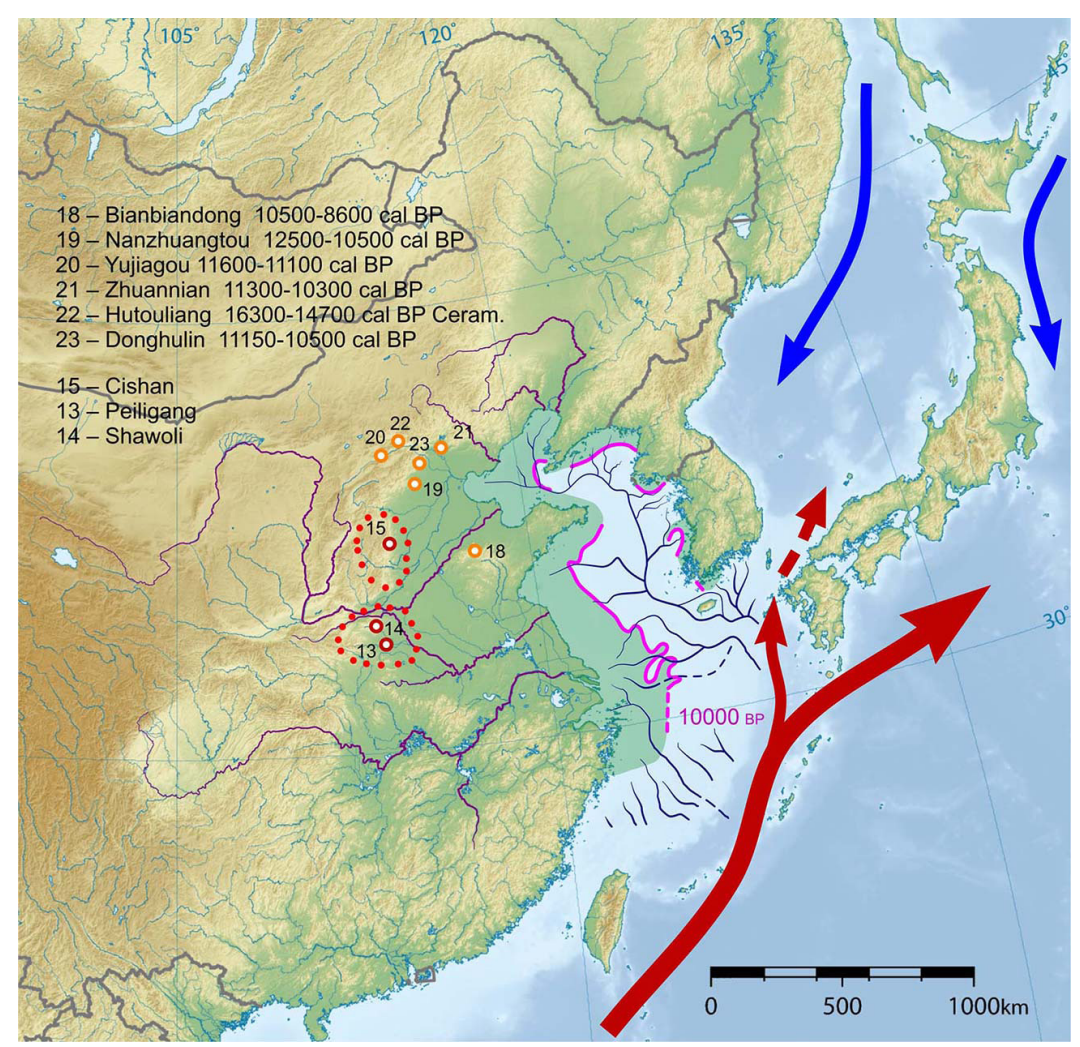

Fig. 3. Reconstruction of the coast of East Asia about 10,000 BP, and archaeological sites of that period

or the territory of Southern Manchurian Plain (about 300 thousand $\mathrm{km}^{2}$ ).

Considering the paleoplain area, the potential territory where domestication processes could take place exceeded the area in Western Asia 6-8 times, but not 2-4 times, as suggested by Ofer Bar-Yosef (Bar-Yosef, 2011: 175).

The estuaries of the paleo-Huang He, paleo-Huai and paleo-Yangtze rivers converged close to each other to the west of Kyushu or were general ones in the period of 15,000 $13,000 \mathrm{cal} \mathrm{BP}$, forming a huge estuary zone. In the area of the Yangtze-Huang He paleo-estuary, a mixture of warm and cold currents was likely to take place, and this fact ensured high initial productivity of marine ecosystems. The impact of the cold current from the Sea of Japan was minimised. The warm paleo-Kuroshio current dominated. It was an artery providing meridional communication of the population of East Asia along the coast and formed a spe- cific vegetation zonality in the coastal zone of East Asia. In this way, the coast was in the zone of tropical and subtropical evergreen forests right up to the strait between the mainland and Kyushu island. Further, in the continental part, they were gradually changed by the zone of coniferous broad-leaved deciduous forests, and then by the zone of loess and arid steppes (Fig. 1). This formed the unique diversity and mosaic nature of resources inland along the coast of East Asia.

There were better landscape and climate conditions for sedentary human habitation in East Asia on the paleoplain irregulated by the rivers and, especially, along paleo-estuaries in the late Pleistocene - early Holocene. These conditions include:

- firstly, a combination of the sea and land food resources, which were characterised by diversity, mosaic structure, stability and local turnover; 
- secondly, the influence of the warm Paleo-Kuroshio current, which provided information exchange and communication in the coastal zone;

- thirdly, the latitudinal orientation of river flows on the paleoplain which provided the information exchange and communication between the coastal and continental regions of East Asia;

- fourthly, positive changes associated with climate warming and changes in vegetation on the paleoplain that occurred earlier than in the middle reaches of the Huang He river. This is especially relevant for the foothills of the Shandong Peninsula highlands. The highland retained moisture, which contributed to the improvement of plant vegetation in the conditions of cold and arid steppes;

- fifthly, the coast formed specific models of behavioural coastal adaptations. They are characterised by a linear resettlement system, settled population, a specific technological complex and cooperation in resources exploitation, a weak dependence of the community members who are not able to work on the main labour force, which resulted in life expectancy, high population density compared to continental areas, control over resource-containing territories and conflicts to get them (Yesner, 1980).

On the whole, the river systems of East Asia made it possible to move both in the meridional and latitudinal directions over long distances easily and without conflicts. This is a very important factor under conditions of food crises caused by climate cooling. In periods when competition for resources increased, survival depended not only on one's own adaptive decisions optimality, but on cooperative relations and/or confrontation with neighbours as well.

Thus, in the late Pleistocene on the paleoplain, hunter-gatherers should, probably, have had a wider resource base than Xiachuan and Shizitan type groups in the middle reaches of the Huang He river. In addition, the population of the paleoplain had to start reacting to environmental changes and make a wider range of adaptive decisions earlier, that also extended to the continent. Against the background of the general trend of climate warming in the late Pleistocene, this favourable picture was spoiled by periodic cooling, that led to food stress among the ancient population.

Considering further events, we have to focus only on the longest and most noticeable climate cooling, implying that there were also short-term ones that did not leave any traces, but influenced the adaptive behaviour of the population. In this way, the cooling of the Older Dryas, separating Bølling and Allerød interstadials was short-term (about 100-150 years), and marked life of several generations. So far, these events are not traced in archaeological materials.

A sharp cooling of the Younger Dryas from about $12,800-12,500$ cal BP to 11,700 11,600 cal BP was a serious disaster for the populations of East Asia (Bar-Yosef, 2011). At this period, hunter-gatherers moved to more favourable habitats, including river valleys, such as Shizitan and Xiachuan (Fig. 2). Another area, where the population could escape from the climate cooling was, probably, the seacoast, where it was warmer at that period. Stabilisation, and low-amplitude marine regression, and, accordingly, the formation of lagoons in the mouths of the rivers flowing into the sea took place (Korotkii, 1985: Fig. 1). The lagoons were areas with high productivity, diversity and sustainability of the ecosystem as a resource base of the population (Laser, 1982). In terms of accessibility and sustainability of resources, they significantly exceeded all other region ecosystems of that period. In conditions of climate cooling, lagoons were the most likely places where the population was concentrated. Their resource base structure made it possible to have full or high degree of sedentary lifestyle. Ethnographic studies show that coastal hunter-gatherers population density was $10-15$ times higher than the corresponding continental population groups (Cook, Heizer, 1968; Yesner, 1980: 730-731; Vostretsov, 2016).

As a result of the cooling, there was a reduction in the resource base, increased mobility, increased competition for resources, intensified use of resources, and the search for alternative survival strategies. It is known that the first domesticated common millet (Pani- 
cum miliaceum) appeared in the settlement of Cishan about 10,300-8,700 cal BP. In this case, according to geneticists, the process of domestication should have started 1,000-2,000 years earlier, that is, during the Younger Dryas cooling (Stevens, Fuller, 2017: 156). The influence of the Older Dryas events should also be taken into account. The subsequent climate warming was associated with a constant, but nonlinear rise in sea level. There was an insignificant coast swamping and conversion of the lagoons into ingressive bays during the transgression. Coastal abrasion and straightening of coastlines led to a decrease in the marine ecosystems productivity. On the one hand, sea level rise constantly forced groups of hunter-gatherer-fishermen move from the coast up the river to the foothills (Fig. 2). There, migrants had to compete for resources with other groups. On the other hand, as a result of the rise in sea levels, the population concentrated around the productive areas of the coast and constantly adapted its life support system to a changing resource base.

\section{The model of transition to agriculture}

Thus, it is assumed that the following phenomena occurred on the paleoplain of the Yellow Sea in the late Pleistocene - early Holocene:

1) the population density and its dynamics constantly increased, competition for resources and information exchange intensified, and the search for the optimal strategy for obtaining resources through intensification was carried out as well;

2) during the climate cooling phases, there were more environmental pressure factors on the population in the conditions of paleoplain, and they were more dynamic than in the middle reaches of the Huang He river;

3) concentrated population with high information exchange and a level of competition for resources under conditions of environmental pressure in the coastal area of the paleoplain was supposed to switch to wild plants cultivation faster, taking into account several millennia experience of gathering them throughout East Asia. It can be illustrated by the appearance of lacquerware items about 10,000 years ago. The complexity of its production can be compared with plants cultivations and requires a certain degree of sedentism.

Further, after the Younger Dryas, in the intervals of 9,700-9,300 BP and 8,200-7,800 BP there were another two climate cooling, accompanied by similar environmental and, probably, social events. Thus, there were much more natural incentives encouraging the population to cultivate plants in the Yellow Sea paleoplain than in the middle course of the Huang He river.

As a result of climate warming, associated with a rise in sea level, rapid resettlement of advanced hunter-gatherers who were, possibly, already cultivators of wild cereals along the waterways to the foothills, started. One example of such a resettlement is a large, long-term Early Neolithic site Donghulin dated 11,500$10,500 \mathrm{cal}$ BP. The population of this site lived in the foothills (Fig. 2, 3), covered with coniferous and deciduous forests dominated by oak and Manchurian walnut. A certain sedentism is documented by permanent fire pits $(0.5-1 \mathrm{~m}$ in diameter), and ash pits, indicating the existence of pit houses. The population used pestles and hand stones, polished stone tools, flat-bottomed pottery decorated with a rope zigzag ornament and tools made of bone and shells. Ornaments from snails (gastropods) and shells of bivalve shells were found in the female burial (Liu, Chen, 2012: 52-55). The analysis of starch residues from the hand stones showed that the population used plants from Hordeum and Agropyron species simultaneously with millet plants (Yang, Perry, 2013: 3176). Researchers who analyse starch residues on the tools from the sites of Donghulin and Nanzhuangtou (11,500$11,000 \mathrm{BP})$ do not exclude that the population attempted to cultivate wild millet plants 1-2 thousand years before Cishan (Fig. 3) (Yang et al., 2011). The population of these sites demonstrates a transition from gathering to a life sustaining strategy with exploitation of a wide range of resources and a certain sedentism (Liu, Chen, 2012: 55-56), and possibly, to experiments with wild plants cultivation.

Around 8,000-7,800 BP the coastline became similar to a modern one. The paleoplain disappeared under water. Further marine trans- 
gression, about 7,400 BP flooded the valley of the lower reaches of the Huang He river for a long time, turning the Shandong highlands into a paleo island with some islands around it (Fig. 4). The settlements of the earliest farmers and advanced hunter-gatherers were under water. Most of them, most likely, were destroyed by coastal abrasion during the marine transgression. That is the reason why the early farmers' sites of the Peiligang-Cishan type known to us are located along the flood zone of the transgression maximum, demonstrating developed forms of technology, material and spiritual culture, and social order rather "unexpectedly" (Fig. 4, 5). At the same time, the vast territory, including the Yellow Sea paleoplain, the lower reaches of the Huang $\mathrm{He}$, Huai and Yangtze rivers remain inaccessible to study. The exceptions are the sites localised on the unflooded and not covered by alluvial deposits, located along the boundary of the Shandong Peninsula highlands. This is another factor that complicates studying the transition to agriculture in East Asia compared with other centres of plant domestication.

These reconstructions should certainly be specified by detailed palaeographic studies in order to identify short-term landscape and climate changes. They will make it possible to determine both, a wider range of adaptive reactions of the population to changing environmental conditions and, possibly, find archaeological evidence for this.

What did the early farmers cultivate? According to isotope analysis of bones, about 8,000 cal PB in the lower reaches of the Huang He river at the Xiaojigshan site, millet already accounted for $25 \%$ of men and women's diet. At the nearby sites located in the northern foothills of Shandong, Jiahu (the Peiligang culture) only rice is known, and at the Yuezhuang site (the Houli culture), dated AMS 7,900 cal BP, 40 seeds of common millet, one seed of foxtail millet, and 26 rice

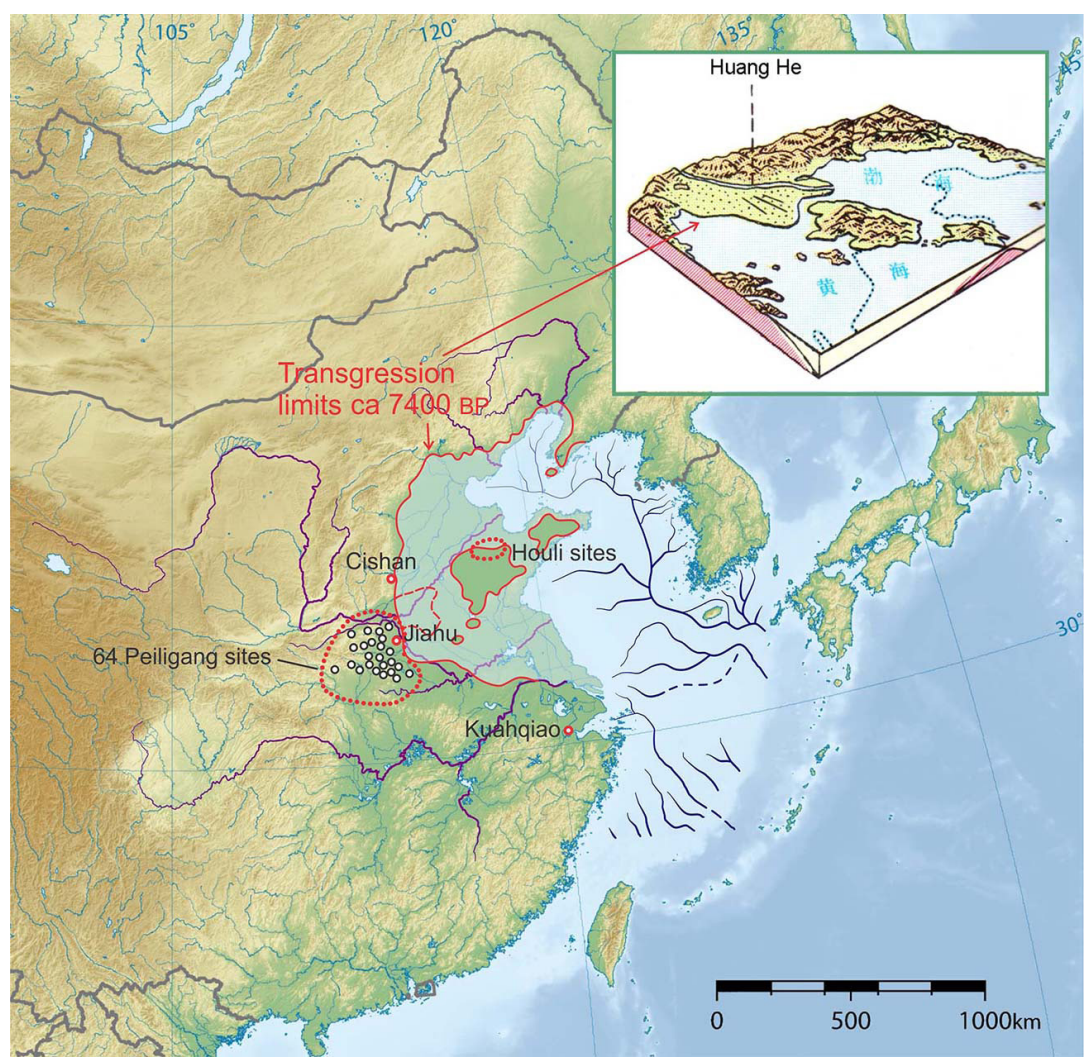

Fig. 4. Reconstruction of the coast of East Asia at the peak of the Atlantic marine transgression about 7,400 BP, and the main archaeological sites ( Upper framing from: Atlas of physical geography, 2000: 111) 


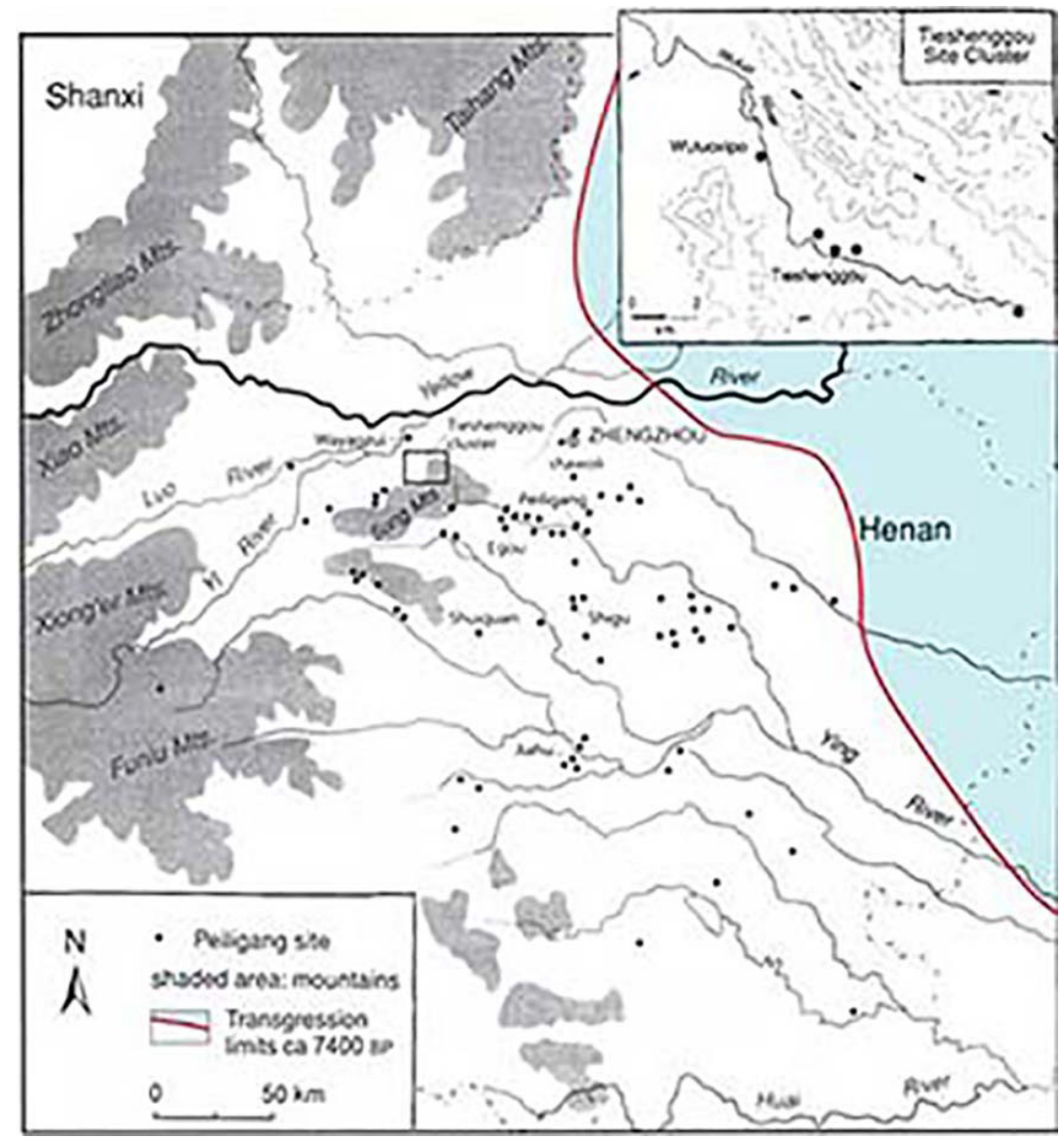

Fig. 5. A section of the reconstruction of the marine transgression border about 7,400 BP in the area of the main territory of the Peiligang culture sites

(Based on: (Lui, Li, 2004) and (Atlas of physical geography, 2000: 111)

seeds were found. Rice was also cultivated on the south of the mouth of the present-day Yangtze river at the Kuahuqiao site, which functioned 7,9007,000 cal BP (Cohen, 2011: 287; Liu, Chen, 2012: 76-80). Considering the reconstruction of that period (Fig. 4), the question, how cultivated, but possibly not yet fully cultivated rice, appeared on the sites that were significantly separated by the ingression bay, arises. If it came from the same centre, then, most likely, it could be on the paleoplain. If there were several centres, then they could be both in different areas of the shrinking paleoplain, and in the floodplains of the modern lower reaches of the Huang He, Huai and Yangtze rivers eroded by Atlantic transgression and secondarily formed by alluvial sediments. It is also reasonable to assume that during the transgres- sion period, when the Shandong paleo island existed, its population, under conditions of limited resources, was forced to concentrate on the same plant gathering areas. As a result, the selection and domestication of cultivated plants should have been accelerated.

At the same time, the population of numerous first early Neolithic settlements still relied on hunting, fishing and gathering, and experimented with wild plants cultivation.

\section{Conclusion}

Thus, all the scarce data suggest that in East Asia in the late Pleistocene the area of the paleoplain on the shelf of the Yellow Sea was the most acceptable in its environmental conditions for the transition to sedentary lifestyle 
and agriculture. It was in its territory that the most dynamic positive changes in the resource base of the population took place.

Vastness, diversity, and easy logistics of the potential territory where wild plants cultivation could take place partially explains its slow pace, noted by the researchers (Stevens, Fuller, 2017: 155-156).

The proposed paleogeographic component of the reconstruction allows to assume what vast and potentially promising for study territory is inaccessible to researchers as a result of climate warming associated with marine transgression in the interval of $15,000-7,400 / 5,000$ years ago. It should be taken into account in future studies.

Probably, the transition to cultivation and domestication of millet and rice started simultaneously on the paleoplain during the cooling of the Older and Younger Dryas and was additionally "motivated" by two subsequent coolings in the early Holocene.
As a result of the sea level rise, the mouths of the Huang $\mathrm{He}$ and the Yangtze River diverged to the south and north, as well as the territorial specialisation of early farmers in cultivation of rice and millet, according to agroclimatic conditions.

The similarity of early Neolithic pottery from the Yangtze and Huang He river basins indicates its origin from the common centre the Yellow Sea paleoplain.

If consider the processes of transition to manufacturing economy in Northern China and the Levant within the framework of the canalised evolution hypothesis, it can be concluded that the population adaptation vector in food production turned out to be predetermined by a set of initial conditions and events that determined a set of possible behaviour variants. In this case, there were two of them: the transition to food production and intensification of its appropriation. The choice of both of these adaptive strategies is observed in East Asia.

\section{References}

Atlas of Physical Geography of China (2000). Beijing. 215 p.

Bar-Yosef, O., (2011). Climatic Fluctuations and Early Faming in West and East Asia. In Current Anthropology, 52(4), 175-193.

Cohen, D.J. (2011). The Beginning of Agriculture in China: Multiregional View. In Current Anthropology, 52(4), 273-293.

Cook, S.P., Heizer, R.P. (1968). Relationships Among Houses, Settlement Areas, and Population in Aboriginal California. In Settlement Archaeology. Palo Alto, 79-116.

Fuller, D.Q., Ling, Q., Yunfei, Z., Zhijun, Z., Xugao, C., Leo. A.H., Guo Ping. S. (2009). The Domestication Process and Domestication Rate in Rice: Spikelet Bases from the Lower Yangtze. In Science, 323, 1607-1610.

Ianshina, O.V. (2008). Perekhod ot paleolita k neolitu v basseine Yaponskogo moria: otkrytiia, fakty, gipotezy [Transition from the Paleolithic to the Neolithic in the Basin of the Sea of Japan: Discoveries, Facts, Hypotheses]. In Khronologiia, periodizatsiia i kroskul'turnye sviazi v kamennom veke: Zamiatinskii sbornik [Chronology, Periodization and Cross-Cultural Communication in the Stone Age: Zamyatinsky Collection], 1. St. Petersburg, Nauka Publishing House, 135-148.

Immamura, K. (1996). Prehistoric Japan. New Perspective of Insular East Asia. London, USL Press, $246 \mathrm{p}$.

Korotkii, A.M. (1985). Quantenary Sea-Level Fluctuation on the Northwestern Shelf of the Japan Sea. In Journal of Coastal Research, (1)3, 293-298.

Laser, P. (1982). Coastal Lagoons. In Nature and Resources, 4, 24-43.

Lui, L. (2004). The Chinese Neolithic: Trajectories to Early States. Cambridge University Press, Cambridge, $329 \mathrm{p}$.

Lui, L. (2008). Grinding Tools, Gathering Nuts, Sedentary Life and the Origin of Agriculture in Prehistoric China. Xian. In Sanqin Chubanshe, 105-132.

Liu, L., Chen, X. (2012). The Archaeology of China. From the Late Paleolithic to the Bronze Age. Cambridge, Univ. Press., 475 p. 
Shevkomud, I.Ia., Ianshina, O.V. (2010). Perekhod ot paleolita k neolitu v Priamur'e: obzor osnovnykh kompleksov i nekotorye problemy [Transition from the Paleolithic to the Neolithic in the Amur Region: an Overview of the Main Complexes and Some Problems]. In Priotkryvaia zavesu tysiachiletii: $k$ 80-letiiu Zhanny Vasil'evny Andreevoi [Opening the Veil of Millennia: to the 80th Anniversary of Zhanna Vasilyevna Andreeva]. Vladivostok, Reya, 50-72.

Shevkomud, I.Ia., Ianshina, O.V. (2012). Nachalo neolita v Priamur'e: poselenie Goncharka-1 [The Beginning of the Neolithic in the Amur Region: The Settlement of Goncharka-1]. St. Petersburg, MFT RAN, $270 \mathrm{p}$.

Stevens, C.J., Fuller, D.Q., (2017). The Spread of Agriculture in Eastern Asia. Archaeological Bases for Hypothetical Farmer/Language Dispersals. In Language Dynamics and Change, 7, 152-186.

Vostretsov, Iu.E. (2012). Poiavlenie i evoliutsiia zemledeliia v Vostochnoi Azii [The Emergence and Evolution of Agriculture in East Asia]. In Materialy Vserossiiskoi nauchnoi konferentsii "Megastruktura Evraziiskogo mira: osnovnye etapy formirovaniia" RFFI, IA RAN [Proc. All-Russia. Conf. "The Megastructure of the Eurasian World: The Main Stages of Formation", RFBR, IA RAS], Moscow, 84-87.

Vostretsov, Iu.E. (2016). Arkheologicheskoe izuchenie povedencheskoi adaptatsii [Archaeological Study of Behavioral Adaptation]. In Rossiia i ATR [Russia and the Pacific], 4, 5-18.

Yang, X., Perry, L., (2013). Identification of Ancient Starch Grains from the Tribe Triticeae in the North China Plain. In Journal of Archaeological Science, 40, 3170-3177.

Yang, X., Wan, Z., Perry, L., Lu, H., Wang, Q., Zhao, C., Li, J., Xie, F., Yu, J., Cui, T., Wang, T., Li, M., Ge, Q. (2011). Early Millet Use in Northern China. In Proc. Natl Acad Sci USA, March 6, 109 (10), 37263730. DOI: 10.1073/pnas.1115430109. Epub 2012 Feb 21.

Yesner, D.R. (1980). Maritime Hunter-Gatherers: Ecology and Prehistory. In Current Anthropology, $21(6), 727-750$. 


\title{
В поисках происхождения земледелия в Восточной Азии
}

\author{
Ю.Е. Вострецов \\ Институт истории, археологии и этнографии \\ народов Дальнего Востока, Дальневосточное отделение РАН \\ Российская Федерачия, Владивосток
}

\begin{abstract}
Аннотация. Неолитизация Восточной Азии происходила на фоне катастрофических ландшафтно-климатических изменений. «Внезапное» появление ранних земледельцев в уже развитом виде типа Пелиган и Сишань изучалось недостаточно. Необходимо прояснить истоки появления и причины широкого распространения как ранних земледельцев, так и «широкого спектра охотников-собирателей». Рассмотрена территория, на которой мог проходить переход к земледелию, а также комплекс факторов давления окружающей среды в конце плейстоцена - начале голоцена, повлиявших на выбор поведенческих стратегий выживания.

Предлагаемая в статье палеогеографическая модель перехода к земледелию в Восточной Азии рассматривает палеоравнину, существовавшую на современном шельфе Желтого моря, как наиболее вероятную область, где могла начаться доместикация растений. Реконструированы тенденции изменения ландшафтной структуры территории палеоравнины в процессе похолоданий и потеплений климата, сопряженных с колебаниями уровня моря. Определены границы максимума трансгрессии моря и зона затопления и разрушения поселений ранних земледельцев. Выяснено, что все сохранившиеся памятники ранних культиваторов и земледельцев находятся по обрамлению границ пика трансгрессии моря, создавая эффект их «внезапного» появления.

В контексте палеогеографических реконструкций выдвинуто предположение, что переход к культивации и одомашниванию просяных и риса начался одновременно на палеоравнине в период похолоданий Древнего и Позднего Дриаса и дополнительно «мотивировался» двумя последующими похолоданиями в начале голоцена. В результате трансгрессии моря произошло расхождение устьев рек Хуанхэ и Янцзы в южном и северном направлении и, соответственно, территориальная специализация ранних земледельцев на культивацию риса и просяных. Сходство некоторых черт материальной культуры раннего неолита Северного и Южного Китая обусловлено происхождением из общего центра.
\end{abstract}

Ключевые слова: происхождение земледелия, археология, палеогеография, Восточная Азия.

Научная специальность: 07.00.00 - исторические науки и археология. 